\section{Order and the square snail}

\section{Stephen Jay Gould}

Games, Sex and Evolution. By John Maynard Smith. Harvester-Wheatsheaf: 1988. Pp.264. £16.95, $\$ 30$.

GREAT popular writing about the natural world may be allocated to one of two lineages, which I shall call franciscan and galilean. The franciscan lineage - from the eponymous St Francis himself, to Henry David Thoreau, to Loren Eiseley in our day - exalts nature in poetic terms, and works for empathy by resonance with the emotions. The galilean lineage may go back to Aristotle, but I designate as its standard-bearer the man who chose to write his two great treatises in the Italian vernacular (not the Latin of church and university), and as dialogues between a teacher and his students. This lineage, while not insensible to aesthetic beauty, emphasizes the loveliness of intellectual solutions, and views natural objects more as doors to understanding than portals to the soul.

Both lineages have their dangers and empty caricatures: overblown language (too often about sunsets) for the franciscans, pedantry and perverting simplification for the galileans. The great galileans, from the founder himself, to T.H. Huxley, to P.B. Medawar in our times, win their laurels for two reasons: because they understand the process of science so intimately (almost always because they practise the art as a profession, and do not only write as journalistic spectators), and because they know that clear, jargon-free prose need not simplify concepts, and that much of the beauty of science lies in its accessible intricacy and ambiguity.

J.B.S. Haldane, the mentor of John Maynard Smith, was the greatest galilean of his generation. He was also, in his technical work, Britain's leading evolutionary theorist. Maynard Smith, Emeritus Professor of Biology at the University of Sussex, succeeded Haldane in this technical arena, and is our foremost darwinian theorist today. In Games, Sex and Evolution, he conveys this work to a wider audience, and proves himself a worthy successor of Haldane in the field of galilean popularization as well.

All but one or two of the 28 pieces in this book have been published before, more than two-thirds of them during this decade, and more than half as book reviews. I cannot gainsay the genre of collecting such items into books, for I have dabbled in it myself. But two major dangers lurk, neither entirely avoided by Maynard Smith: obsolescence and repetition. For the first, most books quickly sink without issue or new edition, and their epiphenomena (including reviews) die with them. To avoid obsolescence, one must do something slightly unfair to the author - use the existence of his book as an excuse to write an essay on something general and enduring (and then purge most parochial passages about the book when you republish the review). Maynard Smith comes close, but his legendary fairness has forbidden the necessary ruthlessness, and too much that is too ephemeral remains.

To avoid repetition, one must edit with a vengeance, another trait lacking in this kindest of men (apparently even towards his own literary children). No one - not Bach, not Handel, not the Lord Himself (or whoever wrote the Good Book) - can avoid telling the same story more than once in a long series of pieces on similar topics. But some redundancies should be eliminated on compilation. One, or even two, of Maynard Smith's lucid explanations of Fisher's theory on sex ratio would have sufficed.

Maynard Smith was originally trained as an engineer, and his mathematical skills far outstrip those of most colleagues in his adopted profession. He knows the limits of his methods, but he loves and dwells upon the power of simple mathematical models, both to pick out recurrent themes and causes amidst the world's complexity, and to suggest connections where disparate subject matter obscures a unity of underlying structure. The title of this book reads like a broad catch-all. But it really marks the doorway to a roman- $\grave{a}$-clef, for the three subjects mark Maynard Smith's most successful application of his mathematical proclivities: his work on the vexatious problem of the evolution of sex (a frightful puzzle in Darwin's world, where organisms struggle only for personal reproductive success and should not dilute their genetic heritage by half in a sexual offspring, when asexual reproduction passes all parental genes to the next generation); his recognition that game theory illuminates much of darwinism, leading to his seminal formulation of ESS (evolutionarily stable strategy) theory; and his critique, as a mathematically minded and unrepentant strict darwinian, of an array of challenges proposed by people who study evolution on other scales (including this reviewer, who greatly values the criticism because it rests upon the two features, alas so rarely found, that characterize all fruitful and honourable intellectual debate - understanding an opponent, and taking his views seriously).

I appreciate both the elegance and power of Maynard Smith's world, a place ordered and dominated by natural selection working in Darwin's favoured mode - on organisms, for the passage of genes to future generations, and leading by struggle to pervasive adaptation. This tidy world of small scale (where Maynard Smith's favourite styles of mathematics apply well) then yields, by smooth extrapolation across all domains of space and time, the pageant of evolution. Maynard Smith allows a plurality of other effects, but confines them to so insignificant a relative frequency that they just don't matter in the totality of his ordered world. Thus, species selection exists and may promote non-adaptive trends in phenotypes by hitch-hiking of numerous features on high speciation rates, but the process is "a very weak one" compared with conventional selection on organisms. Neutralism may be important, but only in a genetic domain below expression in phenotypes - and phenotypes are regulated by the "evolution of adaptations [as] the result of natural selection, and it is adaptation which is the most striking feature of the living world" (p.188). Side consequences and exaptations may produce striking features, but so long as selection triggers the chain, selection shall be the proper centre of explanation.

In my view, Maynard Smith's tidy world exists, but only in a restricted corner of totality, not as a model for everything. Nature is much messier - more imbued with the unpredictable contingencies of history; more replete with important products of selection working both below and above (genes and species) the conventional darwinian emphasis on organisms; more infested in vital ways with nonadaptive side consequences that can overwhelm any trigger of selection. (I don't for a minute accept Maynard Smith's assertion, made on p.82, that "our higher faculties, such as our ability to construct mathematical arguments, or to have religious experiences, [require] an explanation in terms of natural selection". Natural selection may have enlarged our brains for other reasons, but most of what we do with our mentality must arise as side consequences of the flexibility and power of the organization itself.) Maynard Smith tells us that "there cannot be gastropods with square shells" (p.142) - and he's right under the log spiral model of growth. But few shells grow as an ideal log spiral, and I have just finished a technical article on Cerion alberti, the square land snail of Cuba.

The world is not intractable, only gorgeously complex. Galilean rationalism need not cede to franciscan wonder. The American cub scout oath requires members to "be square [meaning honourable in American jargon] and obey the law of the pack". The world can have square snails (indeed it does!) and ordered behaviour - but the domains of evolutionary order extend far beyond the strict darwinian world of natural selection among organisms.

Stephen Jay Gould is a Professor in the Museum of Comparative Zoology, Hanvard University, Cambridge, Massachusetts 02138, USA. 